\title{
Incidence of slime flux in deciduous trees of Southern Ontario
}

\author{
by Hunter Roberts ${ }^{1}$ and Tom Hsiang ${ }^{1, *}$
}

\begin{abstract}
Wetwood is caused by the bacterial infection of the heartwood of deciduous trees which creates a build-up of pressure within the tree and causes fluid to be exuded. The phenomenon of wetwood exudates forming streaks down the bark is known as slime flux. While wetwood is a well-studied subject because of its potential negative impacts on lumber quality, there is a paucity of research on the biology, ecology and distribution of slime flux. The research conducted here in Ontario, Canada used a visual survey to estimate the occurrence of slime flux in deciduous tree species. Local forests and parks in Southern Ontario were surveyed systematically in transects, targeting 100 trees per transect. If slime flux was observed, then source of the flux was also recorded. Among over 1700 trees inspected, 44 had visible signs of slime flux. Analyses showed that slime flux incidence was positively correlated with tree age, and that incidence differed among tree species, with greater incidence in parks than in forests. Slime flux occurred mainly from bark cracks at the bottom four meters of the tree base.
\end{abstract}

Keywords: wetwood, slime flux, hardwoods

\section{RÉSUMÉ}

Le cœur mouillé est provoqué par une infection bactérienne du duramen chez les feuillus qui crée une pression dans larbre et provoque une exsudation de liquide. Ce phénomène d'exsudation lié au cœur mouillé et qui laisse des marques sur lécorce des arbres est connu sous le nom de suintement muqueux. Bien que le cœur mouillé ait été l’objet de nombreuses études en raison de l'impact négatif qu'il peut avoir sur la qualité du bois, on connaît relativement peu de choses sur les aspects biologiques et écologiques ni sur la répartition géographique du suintement muqueux. Cette étude fait état d’un inventaire visuel réalisé en Ontario (Canada) pour évaluer la présence du suintement muqueux chez les essences feuillues. Les forêts et les parcs du Sud de l'Ontario ont donc fait lobjet d'un inventaire systématique au moyen de transects où lon ciblait 100 arbres. Les arbres présentant un suintement muqueux étaient notés et on indiquait en plus la cause du suintement. Sur les quelque 1700 arbres observés, 44 montraient des signes de suintement muqueux. Lanalyse des résultats a montré que l'incidence du suintement muqueux augmentait avec lâge et quelle variait suivant l'essence d’arbre, en plus dêtre plus grande dans les parcs que dans les autres forêts. Le suintement muqueux provenait le plus souvent des fentes de l'écorce dans les quatre mètres du bas de l'arbre.

Mots-clés : cœur mouillé, suintement muqueux, feuillus

\section{Introduction}

Slime flux involves exudations from wounds or cracks of trees resulting in light or dark streaks down the trunk and the viscous exudates may be thick enough to form a layer on the bark (Sinclair and Lyon 2005). Slime flux may be considered an aesthetic and sometimes an odiferous nuisance, but does not harm the tree. The exudates result from a bacterial presence inside the tree called wetwood, which is described as waterlogged wood tissue, with alkaline $\mathrm{pH}$ levels and a microfauna of bacteria (Sinclair and Lyon 2005). Wetwood is considered a natural occurrence, and is not considered detrimental to tree health, although its presence decreases the value of lumber because the waterlogged tissue takes longer to dry and may dry unevenly leading to checking (Sinclair and Lyon 2005). Only when wetwood occurs in the outer living sapwood is it considered pathogenic (Murdoch and Campana 1983).
Bacteria associated with wetwood can enter through wounds on the stem, trunk and especially roots (Sinclair and Lyon 2005). Both aerobic and anaerobic bacteria, along with multiple fungi, mainly yeasts, can infect the sapwood (Hofstra and Stromberg 1999). The microbial invaders in the wood cause fermentation and create carbon dioxide and methane gases which build up pressure within the xylem (Kerrigan et al. 2004). This pressure then forces liquid to be exuded from the xylem out through external openings, whether natural or artificial, and this is known as slime fluxing or "bleeding" (Murdoch and Campana 1983). Liquid is exuded from wounds on the outer surface of the tree including bark cracks, broken limbs, insect- and human- caused damage among other injuries (Murdoch and Campana 1983). When the liquid becomes exposed to air on the outer surface of the tree, it becomes colonized by insects, nematodes and microorgan-

\footnotetext{
${ }^{1}$ Environmental Sciences, University of Guelph, Guelph, Ontario, Canada. N1G 2W1;

${ }^{*}$ Corresponding author: thsiang@uoguelph.ca
} 
isms such as yeasts, which can increase the viscosity or sliminess of the liquid exudates (Kerrigan et al. 2004). The liquid excreted by slime flux may produce a foul smelling odour, and become dark brown leaving a dark stain down the bark on the side of the tree (Schuch and Kelly 2007).

Wetwood remains an area of moderate research because it is involved with staining and drying issues, which can decrease the market value of lumber (Schink and Ward, 1984). However, the biology and ecology of slime flux is a surprisingly barren area of research. The purpose of this research was to survey deciduous trees in southern Ontario from parklands and forests to address the following questions:

(1) Does slime flux incidence differ among species?

(2) Does slime flux incidence differ by tree size?

(3) Is there a difference in slime flux incidence between trees in forests and parks?

(4) Is slime flux associated with particular types of wounds?

\section{Methods}

Forest stands and parks near Guelph and Bradford in Southern Ontario were surveyed for the occurrence of slime flux. Tree species included sugar maple (Acer saccharum Marsh.), silver maple (A. saccharinum L.), black cherry (Prunus serotina Ehrh.), hop hornbeam (Ostrya virginianum (Mill.) K. Koch), American beech (Fagus grandifolia Ehrh.), eastern poplar (Populus deltoides Bartram ex Marsh.), willow (Salix spp.), birch (Betula spp.), basswood (Tilia americana L.), black walnut (Juglans nigra L.), red oak (Quercus rubra L.), white oak (Q. alba L.), and white ash (Fraxinus americana L.).

Linear transects up to $10-\mathrm{m}$ wide were surveyed for up to $500 \mathrm{~m}$ to assess a minimum of 100 trees per transect for the occurrence of slime flux. Parallel transects were done to avoid sample repetition, and only living trees with diameters greater than $10 \mathrm{~cm}$ were assessed. Species and diameters (measured with $\mathrm{DBH}$ tape) of all trees were recorded. When slime flux was apparent on a tree surface, the wound type (canker, crack, branch stub or other) was recorded. Survey sites were chosen based on accessibility and availability, and 10 sites were surveyed in total, four of which were located near Bradford, Ontario and the other six near Guelph, Ontario. Three sites were open area park sites while the other seven were forested areas. The data were subjected to various statistical tests. Analysis of variance and regression analyses as implement in SAS v. 9.1 (SAS Institute, Cary, NC, USA) were used to examine the relationship between slime flux incidence and tree diameter. Chi-squared analyses using SAS was done between incidence and various factors.

\section{Results}

In total 1721 trees were surveyed, only 42 of which had visible symptoms of slime flux (Table 1). Species for which no incidence of slime flux was observed included willow, basswood, black walnut, red oak, white oak, white ash and birch (Table 1). Species in which slime flux incidence occurred included sugar maple, silver maple, black cherry, hop hornbeam, American beech and poplar (Table 1).

Slime flux occurence was greatest in sugar maple (Fig. 1), silver maple (Fig. 2) and black cherry, all between $3 \%$ and $4 \%$ (Table 1). The relationship between DBH and slime flux incidence is presented in Table 2 . The relationship between diam-
Table 1: Tree species, total trees surveyed and incidence of slime flux at 10 locations in southern Ontario.

\begin{tabular}{|c|c|c|c|c|}
\hline \multirow[b]{2}{*}{ Tree } & \multirow[b]{2}{*}{ Species } & \multirow[b]{2}{*}{$\begin{array}{l}\text { Total } \\
\text { trees }\end{array}$} & \multicolumn{2}{|c|}{ Slime flux } \\
\hline & & & Trees & $\begin{array}{c}\text { Inci- } \\
\text { dence (\%) }\end{array}$ \\
\hline sugar maple & Acer saccharum & 593 & 24 & 4.1 \\
\hline silver maple & A. saccharinum & 477 & 14 & 2.9 \\
\hline black cherry & Prunus serotina & 94 & 3 & 3.2 \\
\hline hop hornbeam & Ostrya virginiana & 118 & 1 & 0.9 \\
\hline American beech & Fagus americana & 102 & 1 & 1.0 \\
\hline eastern poplar & Populus deltoides & 65 & 1 & 1.5 \\
\hline American basswood & Tilia americana & 61 & 0 & 0 \\
\hline black walnut & Juglans nigra & 3 & 0 & 0 \\
\hline birch & Betula spp. & 68 & 0 & 0 \\
\hline red oak & Quercus rubra & 4 & 0 & 0 \\
\hline white oak & Q. alba & 5 & 0 & 0 \\
\hline white ash & Fraxinus americana & 66 & 0 & 0 \\
\hline willow & Salix spp. & 65 & 0 & 0 \\
\hline
\end{tabular}

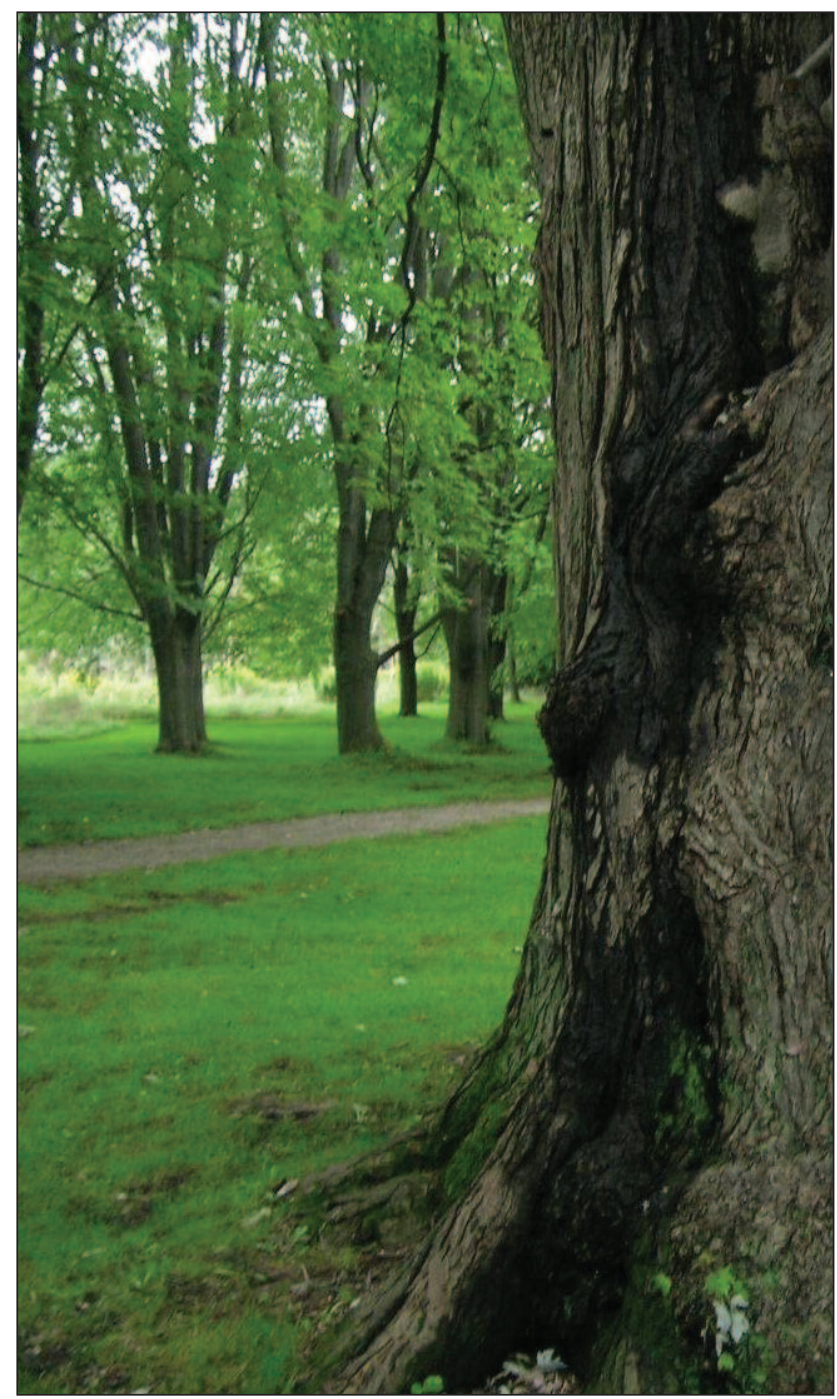

Fig. 1. Slime flux on silver maple at the University of Guelph Arboretum, Guelph, Ontario. 


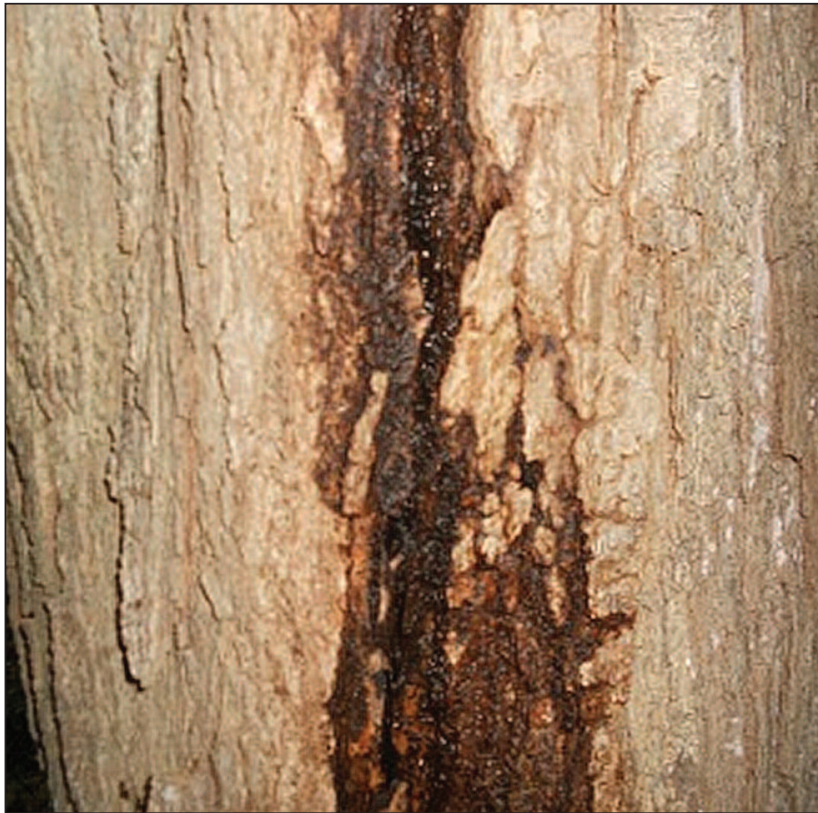

Fig. 2. Slime flux on sugar maple near Bradford Marsh, Ontario.

eter size class and slime flux incidence was further explored by regression analysis yielding:

Slime flux incidence $(\%)=0.263 *(\mathrm{DBH}$ in $\mathrm{cm})-5.71\left(\mathrm{r}^{2}=\right.$ $0.92, \mathrm{p}=0.01$ ).

The slime flux incidence in black cherry was too low (3 out of 94 trees) to properly assess by chi-squared analysis, and the remaining analyses were focused on the the two maple species. For both sugar maple and silver maple, there were statistically significant regressions $(p<0.05)$ of slime flux incidence on diameter class size, and chi-squared testing also found significant differences between incidence in $<50 \mathrm{~cm}$ and above $50 \mathrm{~cm}$ class sizes. In trees over $50 \mathrm{~cm}$ $\mathrm{DBH}$, slime flux occurred in $15.2 \%$ of sugar maples and $6.8 \%$ of silver maples.

In a combined evaluation of sugar and silver maples, slime flux incidence was higher in parks $(9.1 \%)$ than in forests (2.2\%), and a two factor chi-squared test found this to be significantly different $(p<0.0001)$. For trees greater $>50 \mathrm{~cm}$,

Table 2: Diameter class, total number of trees, and incidence of slime flux among 1449 trees in Southern Ontario. Tree species not showing any incidence of slime flux were omitted.

\begin{tabular}{lccc}
\hline & & \multicolumn{2}{c}{ Slime flux } \\
\cline { 3 - 4 } Diameter class $(\mathbf{c m})$ & Total Trees & Trees & Incidence (\%) \\
\hline $10-20$ & 277 & 0 & 0 \\
$20-30$ & 439 & 4 & 0.9 \\
$30-50$ & 481 & 13 & 2.7 \\
$50-80$ & 207 & 19 & 9.2 \\
$>80 \mathrm{~cm}$ & 45 & 8 & 17.8 \\
\hline
\end{tabular}

slime flux incidence was still much higher in parks (14.6\%) than in forests (9.4\%).

For the origin of slime flux on the bark of 44 trees, it was found to occur from cracks $50.0 \%$ of the time; branch stubs, $21.4 \%$; cankers, $26.2 \%$; and other tree wounds, $2.3 \%$. Chisquared tests examined slime flux origin from different sources. It was found to occur significantly more frequently from cracks than cankers $(p=0.0124)$ or branch stubs $(p=$ 0.0019 ). There was no significant difference between occurrence on cankers and branch stub wounds $(\mathrm{p}=0.5271)$.

\section{Discussion}

Slime flux incidence was positively correlated with diameter class, which indicates an increased incidence of slime flux with larger trees. This relationship has been anecdotally observed but as far as we can tell has not previously been quantified. Older trees may have had bacterial wetwood infections for a longer time, as well as greater numbers of and opportunities for crack, canker and branch stub wounds (Hofstra and Stromberg 1999).

Slime flux occurence differed among hardwood species, but the number of trees sampled for most of the species examined was likely too low for an accurate assessment of slime flux incidence and reliable statistical analyses. Sinclair and Lyon (2005) report that wetwood is most common in poplar and elm, with high incidence in maples, mulberry, plane, oaks and willows. With an overall incidence of $2.6 \%$ among the 1721 trees examined, future studies should target at least 500 trees per species for a more accurate assessment. In this study, slime flux incidence was greatest in sugar maple followed by silver maple. These are also the species for which most large diameter specimens were encountered, so the results may be biased.

Slime flux most often occurred from trunk cracks (50\%), but it is uncertain whether the crack was just a point of egress for the wetwood exudates or whether the crack allowed initial infection of the tree. More study is needed on the relationship of cracks and wetwood incidence.

Among tree species showing slime flux, the incidence was found to be higher in parks (9.1\%) than in forests $(2.2 \%)$. This result is biased because only ten trees $>80 \mathrm{~cm}$ were sampled in forests while 27 were surveyed in parks, and the relationship between size and incidence has been demonstrated. But when considering trees greater $>50 \mathrm{~cm}$, slime flux incidence was higher in parks (14.6\%) than in forests $(9.4 \%)$. A plausible reason may be that trees in open settings have more branches and lateral growth than forest trees. Forest trees have greater competition for sunlight and tend to grower taller with less lateral proliferation of branches. The greater number and size of branches in parkland trees compared to forest trees may result in increased numbers of large branch stub wounds from which infections may occur or from which wetwood fluids may exude. Trees with greater direct sunlight exposure on their bark during winter months are also known to have a greater incidence of frost crack wounds (Kubler 1983).

In summary, slime flux incidence among over 1700 hardwood trees in southern Ontairo was found to be $2.6 \%$ and differred between species, with the highest incidence in sugar and silver maples. Diameter was a positive predictor of slime 
flux incidence with zero in trees less than $20 \mathrm{~cm} \mathrm{DBH}$, and almost $20 \%$ in trees $>80 \mathrm{~cm}$ DBH. Slime flux was most often associated with cankers and cracks, and more frequently observed in parklands than in forested trees. For future work, sampling an equally large number of trees of all species in each diameter class, and with at least 500 trees per species will yield more accurate results. The relationships between slime flux, wetwood, wounding, species, size and forest type all require further study.

\section{References}

Hofstra, T.S. and J.C. Stromberg. 1999. Factors associated with wetwood intensity of Populus fremontii (Fremont cottonwood) in Arizona. Great Basin Naturalist 59(1): 85-91.

Kerrigan J., M.T. Smith, J.D. Rogers and G.A. Poot. 2004. Botryozyma mucatilis sp. nov., an anamorphic ascomycetous yeast associated with nematodes in poplar slime flux. FEMS Yeast Research 6: 849-856.
Kubler, H. 1983. Mechanism of frost crack formation in trees - a review and synthesis. Forest Science 29: 559-568.

Murdoch, C.W. and R.J. Campana. 1983. Bacterial species associated with wetwood of elm. Phytopathology 73: 1270-1273.

Schink, B. and J.C. Ward. 1984. Microaerobic and anaerobic bacterial activities involved in formation of wetwood and discoloured wood. IAWA Bulletin 5: 105-109.

Schuch, U.K. and J.J. Kelly. 2007. Mesquite Trees for the Urban Landscape, ARIDUS 19(2): 1-8.

Sinclair, W.A. and H.H. Lyon. 2005. Diseases of Trees and Shrubs. Cornell University Press, Ithaca, NY.

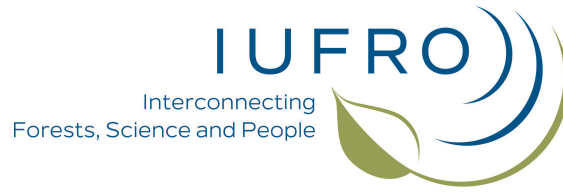

This paper is based on material that was presented at the meeting of IUFRO Working Party 7.02.02 - Foliage, Shoot and Stem Diseases, May 7-11, 2017, Niagara Falls, Ontario, Canada 